\title{
Voices from the water: experience, knowledge, and emotions in long-term ecological research (LTER Italy)
}

\author{
Alessandra Pugnetti \\ CNR-ISMAR, Arsenale Tesa 104, Castello 2737/F, 30122 Venezia, Italy
}

\begin{abstract}
Based on the last decade of activities at the Italian Long-Term Ecological Research network (LTER-Italy), I describe and highlight here some major outcomes and challenges, by picturing different "voices", which we are listening to and we are talking with. Organisms, ecosystems, methodologies, data, researchers, stakeholders and citizens: their voices - i.e., the information which we receive from them, and then interpret and, consequently, express - create our experience and knowledge, which we share with and convey to our contemporaries and future generations. One of the main narrator's voices will be that of plankton: how we "listen" to them, describe and share long-term data and researches, also with the wide public. Through the "voices from the water" I will report and discuss experiences, which have been relevant also to open up the views on the role that science is challenged to play in a world of rapid change, characterized by complexity and contradictions. In particular I will consider: i) those voices coming from various LTER aquatic sites, mainly addressing the comparison among them; ii) how to make these voices most harmonized and audible through the open science approach; and iii) how to put the LTER voices in an effective dialogue with society. Finally, I will share some thoughts about the necessity and the possibility to open the purely scientific cognitive approach to other forms of knowledge, related to our intuition, feelings and empathy.
\end{abstract}

If you are a poet, you will see clearly that there is a cloud floating in this sheet of paper. Without a cloud, there will be no rain; without rain, the trees cannot grow; and without trees, we cannot make paper. (...) If the cloud is not here, the sheet of paper cannot be here either. So we can say that the cloud and the paper inter-are. (...). "To be" is to inter-be. We cannot just be by ourselves alone. We have to inter-be with every other thing. (Tich Nath Han)

\section{INTRODUCTION}

As human beings we realize our living immersed in networks of conversations, which we are not always aware of, that represent both a treasure and a danger. It is actually through the voices that we are listening to, and through the narratives we embrace, that we learn and reflect about the natural world and that we perceive our deep and vital interconnection with or separation from it. We should recognize, both as scientists and as citizens, that we can chose the story and the conversation we take part, because this shapes our responses to any crisis and challenge (Maturana and Davila, 2009).

In Long-Term Ecological Research (LTER) we are engaged in conversations with multiple actors: organisms, ecosystems, methodologies, data, other scientists, citizens, and other typologies of stakeholders, are some of the "voices" that we receive, interpret, and express, creating our experience and knowledge. At the same time, these voices shape and are influenced by our "inner world" the phycological sphere defined by our emotions, thoughts, identities and beliefs - which is considered one of the main drivers of changes in our behaviour and values, enabling actions in uncertain or unprecedented situations (Wamsler and Brink, 2018; Ives et al., 2018, 2019). Indeed, science is not only an individual intellectual or mental process: it is a collective, both organizational and institutional, practice driven by social dynamics. In this pursuing practice, my and other authors' perspectives indicate that the "inner world" is a necessary and positive player (Barbalet, 2002; Koppman et al., 2015).

Grounding on the last decade activities of the Italian LTER network (LTER-Italy; www.lteritalia.it), I will review and report here some experiences, mainly focussing on those "voices from the water" that have been relevant and helpful to delineate my perspective on the role that Ecology (i.e., the branch of science which studies the interrelationships of organisms and their environments, in the complex interplay of functions and processes, information cycling, and cooperative and competitive dynamics) is challenged to play in a world of rapid change, characterized by socio-ecological conflicts and economic contradictions.

The one from plankton (Fig. 1) is the "voice" that I will primarily listen to, as that key ecological community of generally microscopic organisms floating in the waters of the Earth (Hensen, 1887; D'Alelio, 2020) is the main object of my study along the years. An Italian poet, Pierluigi Cappello (2013) writes: "There are words without a body and words with a body. Freedom is a world without a body. Like soul. Like love. They need someone who lends them flesh, blood and boundaries to make them concrete". I like to picture that this is what we do with plankton: we lend our bodies and voices to make them become visible and real, appearing from the waters.

In particular, this paper describes and highlights 
some major outcomes and challenges, in the form of the different voices, which we are listening to and we are conveying within and beyond our community, i.e., the one of scientists. In pursuing this aim, I will be: i) listening to the voices coming from the LTER aquatic sites, mainly addressing the comparison among them; ii) suggesting how to make these LTER voices more harmonized and audible through the open science approach; and, finally, iii) illustrating my perspective on how getting the LTER voices engaged in an effective dialogue with Society. In the end, I will share some thoughts about the chance, and necessity, to open the purely scientific cognitive approach to other forms of knowledge, integrating our inner world.

\section{VOICES FROM LTER-ITALY}

\section{LTER-Italy aquatic sites and plankton}

The principal aim of LTER is understanding, analysing, and monitoring changes in ecosystem patterns and processes over extended periods of time, typically decades. LTER is prevalently organised in networks of sites and platforms, at the national (e.g., LTER-Italy), continental (e.g., European, LTER-Europe: http://www.ltereurope.net/) and global level (LTER-International, ILTER: www.ilter.network), where approaches and interpretations of ongoing ecological processes are developed (Mirtl et al., 2018; Mollenhauer et al., 2018), also with the aim of creating a legacy of well-designed and documented knowledge for future generations.

Amongst the many papers that have been issued in the last decades about LTER research, networks and sites, I have been - and I still am - motivated by two of them, which are the voices providing me with both the knowledge and the language - words and metaphors - to convey it. Those seminal papers and their Authors are still influencing and nourishing my inner world as well, supporting my emotional perspective and my long-lasting bond with LTER.

The first paper was written by Magnuson (1990) and gifted me with the metaphor of "the invisible present", which express powerfully the role of LTER in connecting the current environmental (both physical and biological) conditions to the past, in order to understand where we are and where we wish to move toward. In this paper, there is also a clear call for responsibility in LTER: the invisible present is actually defined as the time scale within which our responsibilities for the Earth are most evident since, within this time scale, ecosystems change during our lifetimes and the lifetimes of our children and our grandchildren. The second seminal paper was written by Peters (2010) and made me understand and appreciate the value of LTER sites, by bringing together their role along three different dimensions and ecological strategies: the long (long-term studies), the deep (short-term, patternprocess studies for deep understanding) and the broad (observation networks of sites for broad-scale patterns). The
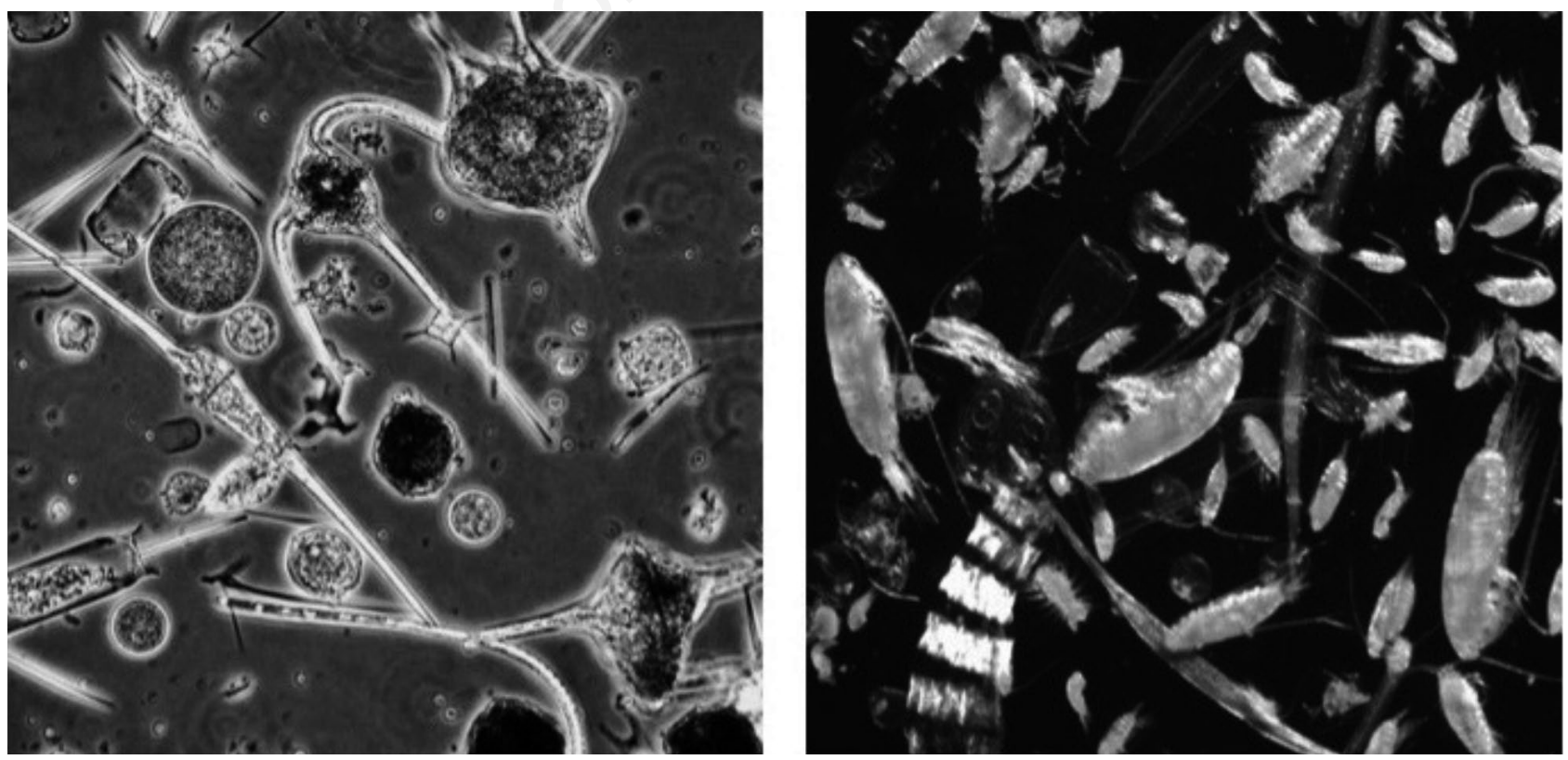

Fig. 1. Optic microscopy view of a mixed winter phytoplankton (left) and zooplankton (right) community gathered at the LTER site Gulf of Venice, Northern Adriatic Sea. Pictures courtesy of Stefania Finotto (phytoplankton), and Elisa Camatti and Marco Pansera (zooplankton). 
process of construction and consolidation of the Italian LTER network, to which I contributed along with many other colleagues, have always been guided for me by the voices expressed by these two Authors, and have provided me the foundation of any further conceptual enrichment.

The LTER-Italy network has been established in 2006, year that marks its official affiliation to ILTER (i.e., the 'International' LTER network). The story of LTER-Italy has been driven by professional collaboration and friendship, with many events and memories that promoted the long-lasting connection within this wide community. In the past 15 years, the development of LTER-Italy has been tightly connected with that of LTER-Europe, even more now that the European network has entered a new phase, while developing the eLTER Research Infrastructure (eLTER RI) as a formally recognised ESFRI Research Infrastructure, since 2018. LTER-Italy currently consists of 79 research sites, organized in 25 parent sites (i.e., made by multiple research sites), managed and coordinated by public research institutions, universities, and environmental agencies. The sites represent the main ecosystem ty- pologies of Italy: they include terrestrial, freshwater, transitional and coastal marine environments, giving the network a marked interdisciplinary brand.

Forty sites, i.e. more than half of the total LTER-Italy sites, are aquatic (Tab. 1). They are distributed along the whole Peninsula and they include the most common Italian lake typologies (large and deep subalpine lakes, small and shallow mountain lakes and reservoirs), the main Italian lagoons and relevant marine coastal ecosystems. Long-term series of data on plankton (phyto-and/or zooplankton) dynamics have been collected during the last forty years at most LTER-Italy aquatic sites, providing an invaluable empirical and rigorous knowledge for the sustainable management of aquatic resources, considering that in the last decades most aquatic ecosystems in Italy have undergone significant ecological changes.

The voices from LTER-Italy aquatic sites - from the large subalpine lakes to mountain and artificial lakes, from lagoons to marine coastal ecosystems - were gathered and compared by 54 Authors in a first, and unique until now, synoptic and trans-domain overview of plank-

Tab. 1. List of the LTER-Italy aquatic sites involved in the papers cited in the text and/or in the Cammini LTER initiative. For the full list of the LTER-Italy aquatic sites see: www.lteritalia.it

\begin{tabular}{|c|c|c|c|c|c|c|c|c|}
\hline $\begin{array}{l}\text { LTER-Italy } \\
\text { Parent Site }\end{array}$ & $\begin{array}{l}\text { LTER-Italy } \\
\text { Research site }\end{array}$ & $\begin{array}{l}\text { Ecosystem } \\
\text { typology }\end{array}$ & $\begin{array}{c}\text { Morabito } \\
\text { et al., } \\
2018\end{array}$ & $\begin{array}{c}\text { Rogora } \\
\text { et al., } \\
2018\end{array}$ & $\begin{array}{c}\text { Zingone } \\
\text { et al., } \\
2019\end{array}$ & $\begin{array}{c}\text { Tanentzap } \\
\text { et al. } \\
2020\end{array}$ & $\begin{array}{l}\text { Pilotto } \\
\text { et al. } \\
2020\end{array}$ & $\begin{array}{c}\text { Cammini } \\
\text { LTER }\end{array}$ \\
\hline Lake Ecosystem of Sardinia & Lake Bidighinzu & Artificial lake & $\mathrm{X}$ & & & & $\mathrm{X}$ & \\
\hline Lake Ecosystem of Sardinia & Lake Sos-Canales & Artificial lake & $\mathrm{X}$ & & & & & \\
\hline Southern Alpine lakes & Lake Como & Deep subalpine lake & $\mathrm{X}$ & & & & & \\
\hline Southern Alpine lakes & Lake Garda & Deep subalpine lake & $\mathrm{X}$ & & & & & $\mathrm{X}$ \\
\hline Southern Alpine lakes & Lake Iseo & Deep subalpine lake & $\mathrm{X}$ & & & & & \\
\hline Southern Alpine lakes & Lake Maggiore & Deep subalpine lake & $\mathrm{X}$ & & & $\mathrm{X}$ & & $\mathrm{X}$ \\
\hline Southern Alpine lakes & Lake Orta & Deep subalpine lake & $\mathrm{X}$ & & & & & \\
\hline Mountain lakes & Lago Anterselva & Alpine lake & & & & & $\mathrm{X}$ & \\
\hline Mountain lakes & Lago piccolo di Monticoli & Alpine lake & & & & & $\mathrm{X}$ & \\
\hline Mountain lakes & Lake Paione Superiore & Alpine lake & & $\mathrm{X}$ & & & & $\mathrm{X}$ \\
\hline Mountain lakes & Lake Paione Inferiore & Alpine lake & & $\mathrm{X}$ & & & & $\mathrm{X}$ \\
\hline Mountain lakes & Lake Santo Parmense & Appennine lake & $\mathrm{X}$ & $\mathrm{X}$ & & & & \\
\hline Mountain lakes & Lake Scuro Parmense & Appennine lake & $\mathrm{X}$ & $\mathrm{X}$ & & & & \\
\hline Mountain lakes & Lake Tovel & Alpine lake & $\mathrm{X}$ & & & & & $\mathrm{X}$ \\
\hline- & Lake Trasimeno & Shallow lake & $\mathrm{X}$ & & & & & \\
\hline Lagoons of Salento & Alimini & Coastal lagoon & $\mathrm{X}$ & & & & & \\
\hline Lagoons of Salento & Aquatina & Coastal lagoon & $\mathrm{X}$ & & & & & \\
\hline Marine Ecosystems of Sardinia & Lagoon of Cabras & Coastal lagoon & $\mathrm{X}$ & & & & & \\
\hline- & Mar Piccolo of Taranto & Coastal lagoon & $\mathrm{X}$ & & & & & $\mathrm{X}$ \\
\hline- & Lagoon of Venice & Coastal lagoon & $\mathrm{X}$ & & & & $\mathrm{X}$ & $\mathrm{X}$ \\
\hline Gulf of Naples & Marechiara & Mediterranean Shelf and sea & $\mathrm{X}$ & & $\mathrm{X}$ & & & $\mathrm{X}$ \\
\hline Marine Ecosystems of Sardinia & Gulf of Olbia & Mediterranean Shelf and sea & $\mathrm{X}$ & & & & & \\
\hline Northern Adriatic Sea & Gulf of Trieste & Mediterranean Shelf and sea & $\mathrm{X}$ & & & & & $\mathrm{X}$ \\
\hline Northern Adriatic Sea & Gulf of Venice & Mediterranean Shelf and sea & $\mathrm{X}$ & & & & $\mathrm{X}$ & $\mathrm{X}$ \\
\hline Ligurian Sea & Portofino Promontory & Mediterranean Shelf and sea & $\mathrm{X}$ & & & & & \\
\hline Northern Adriatic Sea & Senigallia-Susak transect & Mediterranean Shelf and sea & $\mathrm{X}$ & & & & & \\
\hline
\end{tabular}


ton dynamics, based mainly on published studies, but also checked and complemented with unpublished information (Morabito et al., 2018). This paper is indissolubly associated to the figure of Giuseppe Morabito, who, during the paper drafting, passed away for a sudden upsurge of the illness that hit him some years before. Giuseppe was a strong and much appreciated voice in phytoplankton ecology, both in Italy and abroad. But, above all, he was a friend for most of us. The "voice" of Giuseppe, both the remembrance of its tone and laughs and the ecological conceptualization it brought to us, accompanied us for many months following his death and it was crystalized in our paper.

In the article by Morabito et al. (2018), a general conceptual framework was achieved, connecting the large and small scales in a chain of events embracing the whole 'aquatic continuum', where the plankton responses appear to depend mainly on the trophic state of the ecosystems and on the strength of the local anthropogenic disturbance. Actually, the long-term patterns were linked to a variety of factors, differently identified in: i) the physical and meteorological conditions; ii) the combination of bottom-up and top-down controlling factors; iii) the progressive improvement of wastewater treatment; and iv) the contemporary decrease of precipitations and nutrient loading from inflowing rivers. Besides, the marked increase in water temperature over the last decades was a trait shared by many Italian marine and freshwater environments: these results concur to confirm the significant warming of marine ecosystems and largest lakes, in line with the outcome of measurements recorded at the global scale.

Some of the voices of LTER-Italy aquatic sites (Tab. 1) joined the ones coming from the terrestrial sites, in two cross-domain studies conducted at the European level (Rogora et al., 2018; Pilotto et al., 2020). The first of these studies (Rogora et al., 2018) offers a comprehensive overview and synthesis on the effects of climate change in different mountain ecosystems, considering several LTER sites, both terrestrial and freshwater (lakes and streams), distributed along the Apennines (Italy) and the Alps (Italy, Switzerland and Austria). Rogora et al. (2018) focus on the change in vegetation cover and carbon uptake, on the alteration of biogeochemical cycles in soils and water, and on the change in phenology and biological diversity in mountain ecosystems; data showed varying levels of effects in response to climate change, which has a prevalent indirect impact, resulting from multiple interactions. For instance, the interannual variability in the duration of the snow cover appeared to play a key role, affecting nutrient cycles both in soils and in surface waters and influencing the biological communities as well.

The second cross-site study mentioned herein (Pilotto et al., 2020) is a meta-analysis of multidecadal biodiver- sity series in Europe, aiming to fully understand the patterns of local biodiversity change and the discrepancies between local and global biodiversity trends. The study considers 161 long-term series from 115 marine, freshwater and terrestrial sites, mostly belonging to LTER-Europe, in 21 European countries, covering nine biogeographic regions, three realms and eight taxonomic groups. This wide scale, long-term study showed that a significant heterogeneity in the degree and direction of change in biodiversity metrics (i.e., the criteria used to 'measure' the level of biodiversity) exists at the continental spatial scale, demonstrating that biodiversity changes at local scale are often complex and cannot be easily generalized.

Going back to the three ecological strategies described by Peters (2010), the papers by Morabito et al. (2018), Rogora et al. (2018) and Pilotto et al. (2020) are examples of the "long" and the "broad", which both represent essential components of the LTER networks and of eLTERRI, i.e., the wide scale systematic coverage of major terrestrial and aquatic environments, which can provide a whole-system multi-scale approach for comparative ecological analysis (Mirtl et al., 2018).

Amongst the LTER-Italy aquatic sites, there are also many examples of the "deep", meant as the development of different kinds of specific research questions and complementary studies, emerging from the long-term observations, and which provide valuable interpretative tools that enhance the informative significance of the long-term series themselves. I report here only two examples for all, concerning the LTER site MareChiara (LTER-MC) in the Gulf of Naples (Zingone et al., 2019) and the Lake Maggiore (Tanentzap et al., 2020), two iconic LTER sites as for the coastal marine environments and the large lakes, respectively (Fig. 2).

The paper by Zingone et al. (2019) explicitly addresses how the LTER local site, specifically, the LTERMareChiara programme conducted with sampling 2 miles off downtown Naples, proved to be relevant not only to trace plankton changes at different scales and under different environmental conditions across three decades, but this effort set a natural laboratory up, which has become a source of many inspiring voices for complementary research widening considerably the knowledge of the planktonic organisms and of the whole ecosystem functioning. A high number of phytoplankton species has been uncovered (both with microscopy-detailed taxonomic studies and biomolecular approaches), elucidating also the role of 'crypticity' in shaping natural diversity; the different phases in the life cycles of individual species have been finely described, with a consequent improvement of our ability to interpret seasonal and biogeographical patterns.

At the other side of the 'salinity border', the long-time 
sseries of Lake Maggiore was used to thoroughly assess how the warming lake temperatures, up to $2 \mathrm{C}$, might have restructured the pelagic food webs from 1981 to 2008 (Tanentzap et al., 2020). This paper addressed the thermal responses of the different trophic levels, associating temperatures with population dynamics, an issue whose evidence remain scarce in nature. As the lake warmed, the food web shifted, in terms of numerical abundance, towards predators occupying middle trophic positions, strengthening the top-down structuring of the food web.

All the above-mentioned valuable studies addressed the plankton ecology and/or the functioning of ecosystem and their changes with the well-established cognitive approach, where we - as human beings in our role of scientists - observe the environment. Field activities, critical data analysis and discussion, writing up the results: these, well-motivated and conscious, actions are all necessary and enjoyable activities taken by our rational mind, which allow obtaining valuable knowledge and objectively based information on how ecosystems work and change.

However, I guess that we all have experienced another type of knowledge of the sites we are studying, based on different qualities that are connected with our emotions
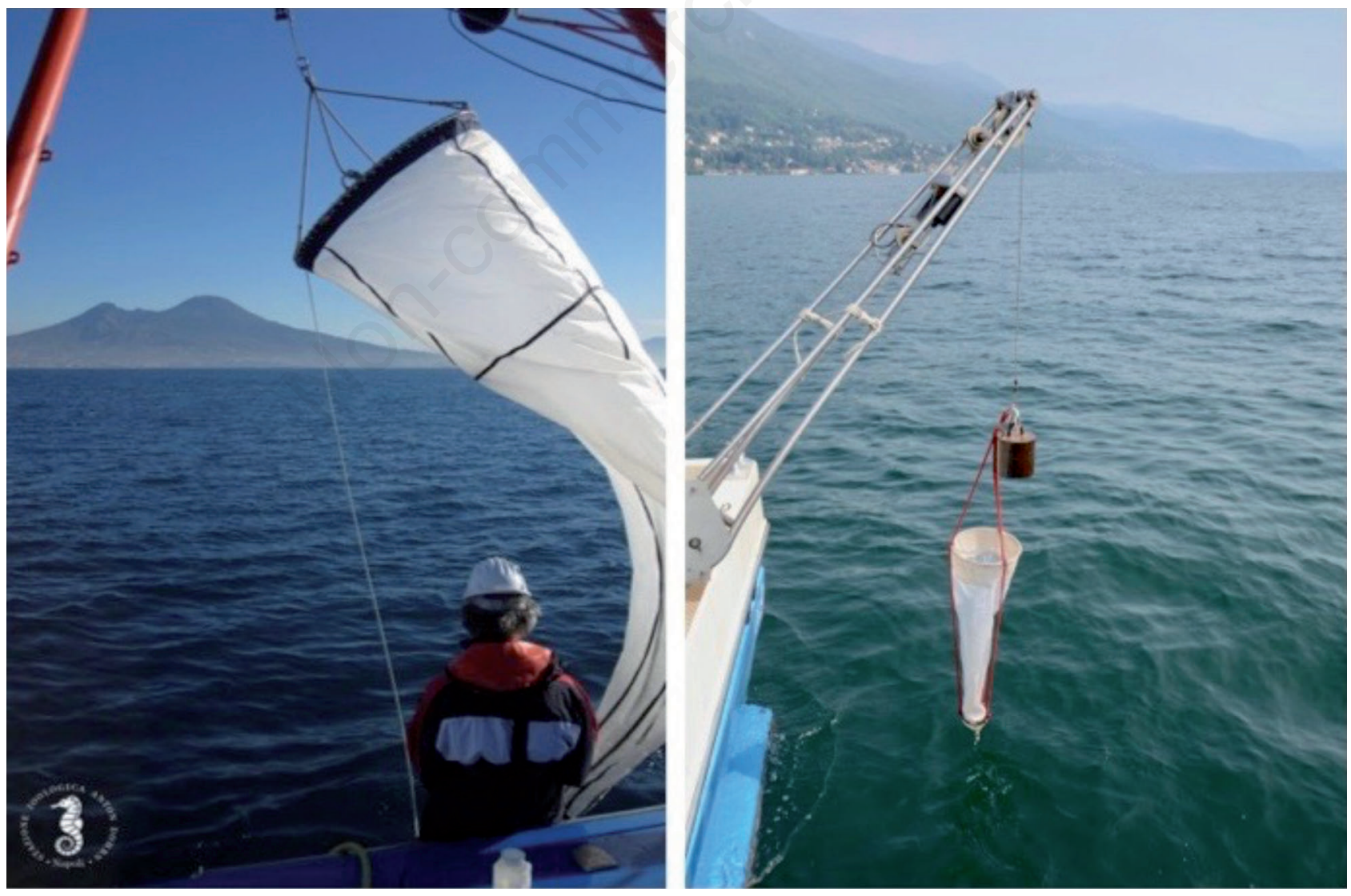

Fig. 2. LTER - Plankton sampling activities at the LTER sites MC - Gulf of Naples (left) and Lake Maggiore (right). Pictures courtesy of Maria Grazia Mazzocchi and Gabriele Tartari, respectively. and with a peculiar kind of perception, which deeply bond us with Nature, beyond scientific and rationale knowledge and words. This brings us to what is called "Affective Ecology" (Barbiero, 2011 and 2017), a new discipline grounded on Ecology and dealing, indeed, with our connecting with Nature. Affective Ecology is epistemologically founded on two scientific hypotheses: the biophilia (Wilson, 1984), which manifests the innate learning rules evolved in the human species to connect and govern our relationship with Nature; and the theory of multiple intelligence (Gardner, 1983), which individuate different manifestations of human intelligence, one of which can be defined as naturalist intelligence (Gardner, 1999).

In the scientific papers we write, there is usually (and understandably) virtually no place for an exploration of affective ecology and the qualities it brings, since these latter are considered to be just subjective impressions of our own, suitable for poetry perhaps, but not for a 'business-as-usual' approach to science. Instead, cognitive Ecology and Affective Ecology can act in synergy within one another, thus giving rise to a virtuous circle: on the one hand, establishing an affective connection with the natural world stimulates the desire to know nature at a 
deeper level; conversely, a deeper ecological knowledge may stimulate a more intimate relationship between nature and the mankind (Harding, 2011).

\section{Are the LTER-Italy "voices" harmonized and open?}

Based on the cross-site studies presented above, two major interconnected issues appear as shared at the European and global levels (Mirtl et al., 2018): i) the heterogeneity of long-term series, for what concerns series lengths, survey schemes, and methodologies; and ii) the inadequate accessibility and availability of the dataset, which frequently lack appropriate data management plans and sharing procedures. These issues stem intrinsically from the most frequent establishment process of national networks at the European level, including the Italian one, which were mainly driven by bottom-up efforts, i.e., making the best use of the existing long-term ecological activities and facilities, without any prior harmonization and agreement around data management procedures and policies.

At the global and European levels both aspects are tackled with different tools and initiatives, namely by the adoption of: i) the Ecological Metadata Language (EML, Michener et al., 1997) as a common metadata language (Vanderbilt et al., 2010); ii) the Environmental Thesaurus (EnvThes, http://vocabs.ceh.ac.uk/evn/tbl/envthes.evn; Schentz et al., 2013), which provide a common and stable semantic backbone for documenting research products; and iii) the Dynamic Ecological Information Management System - Site and Dataset Registry (DEIMS-SDR), a research and monitoring site registry (https://www.deims.org/; Wohner et al., 2019) that allows describing and identifying in situ sites and facilities (stations, sensors, datasets, persons), generating persistent, unique and resolvable identifiers for each site, and also documenting associated data linked to each site. Besides, a core set of biotic and abiotic variables is under definition, for better comparisons across spatial scales and increase of the usage of LTER data, based on the already existing frameworks and approaches at the global level (Haase, 2018). These core set of recommended variables consider and link, currently, both the Ecosystem Integrity Framework (Mueller, 2005) and the Essential Biodiversity Variables (EBV; Pereira et al., 2013), within an integrated approach to be applied to terrestrial, freshwater, transitional and marine ecosystems. This approach could support holistic ecosystem research, ensuring that individual sites cover the most important features of ecosystems, promoting the comparability and interoperability of data between different sites and monitoring networks, and contributing to harmonize field research globally.

To this respect, Zilioli et al. (2019) tested the level of maturity of LTER-Italy at contributing to the EBVs' framework by i) investigating how many and which cat- egories of LTER sites currently provide datasets suitable for measuring the two EBVs "Species Distribution" and "Species Abundance"; and ii) mining the information which is structured and publicly shared by site managers through DEIMS-SDR. Through this analysis, a first overview of EBVs monitored in LTER-Italy and the corresponding data management practices has been provided, as well as an assessment of the interoperability of the network with respect to other research organisations. The study evidenced a documented capacity to provide essential measures through the information system DEIMSSDR, but at the same time the need to support the community and to optimise the EBVs' information retrieval to improve the assessment and hence the effectiveness of LTER as an observing system.

The technical, cultural and social aspects of data sharing are considered as crucial in ILTER, which thoroughly address them with a general and full agreement, in principle, on open data at the global scale (Vanderbilt et al., 2015; Vanderbilt and Gaiser, 2017; Shin et al., 2019). However, putting the open science principles into practice is still an issue in many of the national member networks and at the local level, calling for the development of practical case studies. One of them has been recently carried out in the LTER-Italy framework: it regarded the release, with open access, of a long term marine dataset of water quality and plankton data collected in the Northern Adriatic Sea, in 50 years, from 1965 to 2015 (http://doi.org/10.5281/zenodo.3516717; Acri et al., 2019, 2020). This goal was achieved by embracing an open vision extended to the whole research lifecycle (Minelli et al., 2018a, 2018b): from research idea to results and data, from metadata to methods and software. Open science actually involves a broad and comprehensive view, for making the various research steps accessible, reusable, and understandable.

Besides the most technical aspects, which can be found in the above-cited papers and that are not reported here, I wish to stress the cultural and human ones, which connected the LTER voices beyond time and space. Indeed, a heterogeneous working group, made by field ecologists and data management scientists as well as by retired researchers, worked together since the beginning and along the whole process, with the goal of sharing and harmonizing also the different experiences, needs, and points of view, and of demonstrating that a change of vision is possible, from "publishing as soon as possible" to "sharing and collaborating" (Moedas, 2015). All the LTERItaly scientists involved agreed with open science and they were willing to know better what open science actually could imply in practical terms. Uncertainty to openly share the data was mainly due to the concern of getting proper acknowledgments to the data producers and about the extra time needed to accomplish the whole process, 
which was seen as a further workload, difficult to hold up. Moreover, the opportunities of publishing datasets and data-papers were also poorly known and considered with scepticism, mainly for the low impacts on the professional careers. Actually, indexing published datasets on Web of Science and the practice of data papers is quite a new one, which needs still to enter in the publication habits.

Working side by side in this multidisciplinary group allowed to express and examine honestly all the difficulties encountered, trying to find together the possible solutions and including, as essential parts and outcomes of the process itself, also the cultural resistances and practical challenges. The whole process required sharing, in a concrete and pragmatic way, visions, tools, and languages. One of the unexpected products was, for instance, a glossary (Scovacricchi, 2020) initially started as a joke after each meeting, containing all the terms and acronyms that were used in the informatics field and were not understandable by field researchers. This glossary has been then organized, transformed into a report, openly accessible (http://doi.org/10.5281/zenodo.4302115), to be exploited as a tool to learn and share terminologies that often could hamper the integration between different expertise.

Finally, I wish to emphasize the contribution to LTER studies provided by retired researchers, who revealed to be extremely precious, for the knowledge they owned about the oldest data, which they gathered personally, and for their unaltered memories, tightly connected with personal stories, which were reviving the data from the past. Thanks to them, we became more aware of the human dimension behind the dataset and of the crucial importance of fostering open science also for allowing the creation of links among the past, the present and the future. This brings us back to the paper by Magnuson (1990) and to his call for the responsibility in LTER studies: transmitting openly the data and knowledge, inspired by the vision of continuity across generation, can actually move us from a pure cognitive experience to an enlivening and rewarding one.

\section{LTER-Italy voices in dialogue with society}

There is a wide and growing recognition that the environment must be viewed and studied as a social-ecological system, where ecological research becomes also a cultural process, not only a scientific one (Haberl et al., 2006). The integration of social sciences in LTER networks is a recognized priority (Singh et al., 2013; Mirtl et al., 2018, Dick et al., 2018): socio-ecological research is conducted worldwide in LTER networks, aiming at involving a broad stakeholder community in measurements in the co-design of investigation practices and also in the definition of research priorities (Haberl et al., 2006; Mauz et al., 2012; Dick et al., 2018). The LTER networks may therefore represent an appropriate and suitable context where new and different forms of communication and public participation and engagement could be experimented, sharing the voices of LTER with the civil society in a mutual relationship. Indeed, ecosystem and biodiversity too often remain abstractions and conceptualizations, unless new methodologies in science communication and education are developed, with new voices and words able to convey different perceptions, embedded in the language, in the culture, and in the daily experiences (Monbiot, 2017; Gray and Colucci Gray, 2018).

Aiming at making the public more familiar with the different LTER ecosystems and with the LTER vision and aims, LTER-Italy researchers planned and realized, from 2015 to 2019, the informal science-communication initiative called Cammini LTER (D'Alelio et al., 2016; Bergami et al., 2018; L'Astorina et al., 2018a; Pugnetti et al., 2019). During Cammini, researches "walked, cycled and kayaked" along itineraries, which connected two or more LTER sites, creating a physical and visible movement of researchers towards and with citizens, sharing informal events and communication activities, in close relationship and cooperation with the territories crossed, which were quite heterogeneous in size (from big towns to small villages) and audience (from school children to elderly people, from lay people to territorial managers, such as foresters, ecological and alpine guards, local environmental associations). Thirteen trails were realized in 5 years, most of them involving LTER aquatic sites (Tab. 1; Bergami et al., 2018) and letting spread the voice of plankton in very different context, across seas, lagoons, lakes, and also on the land.

The initiatives realized in the trails covered most of the communication typologies mentioned in the literature (Bergami et al., 2018; L'Astorina et al., 2018b; Pugnetti et al., 2019). The science communication system can be, indeed, compared someway to an ecosystem (Davies and Horst 2016), where various communication practices coexist, occupying diverse and self-consistent niches, all quite interconnected. In the Cammini, traditional (e.g., press releases, public conferences, tweets and post on the social networks, reports on blogs) and experimental (Fig. 3; e.g., sharing of the LTER activities at the sites, with samplings of the different ecosystems' components and microscopy sessions of plankton and benthos) activities were carried out along each trail, aiming at highlighting the relevance of LTER in the territories crossed and the role of the institutions involved. To these activities, more participative and inclusive initiatives were added, such as those of citizen science (Criscuolo et al., 2018a, 2018b), the Biobliotz (Petriccione, 2018) and the Sea Futuring Tours (Fig. 3; L'Astorina et al., 2018c). These lasts consist in a new form of public engagement, aimed at fostering awareness and responsibility towards the surrounding environment, the sea in this case: secondary school students 
of Naples and Taranto were invited and guided, through different cognitive and sensorial experiences, to imagine the future of the sea they lived by, the Gulf of Naples and the Mar Piccolo.

The multifaceted communication activities and methods experienced during Cammini reveals the heterogeneity of expertise, interests and expectations of LTER scientists: i) experience new languages to make science most accessible and attractive; ii) activate synergies between expert and local knowledge in a mutual exchange; and iii) recover or strengthen the emotional and affective link with our work and with the natural environment.

Cammini can be considered as a part of a long-lasting tradition, where walking is considered the most intimate way to engage with the landscape, offering privileged insights and knowledge into both places and self (Solnit, 2000), reinforcing the connection with the natural environment (Maturana and Varela, 1998; Varela et al., 1991).
In the physical gesture of "opening to the world" with the body and the senses (Le Breton, 2000), most researchers left behind, not only symbolically, the comfort zone they were used to (e.g. the desks, the laboratories, the mental schemes, the thematic congresses) to experiment informal and not mediated communication modalities, activating empathy with the people and places and overcoming the sense of separation and distance that often characterize the relations between science and society (L'Astorina et al., 2018a).

\section{CONCLUSIVE MUSINGS}

In this paper I evidenced some crucial aspects of LTER-Italy activities at the aquatic sites, with emphasis on plankton, which guiding voice brought me to deal different issues that have been - and still are - at stake in the current development of the national network and of
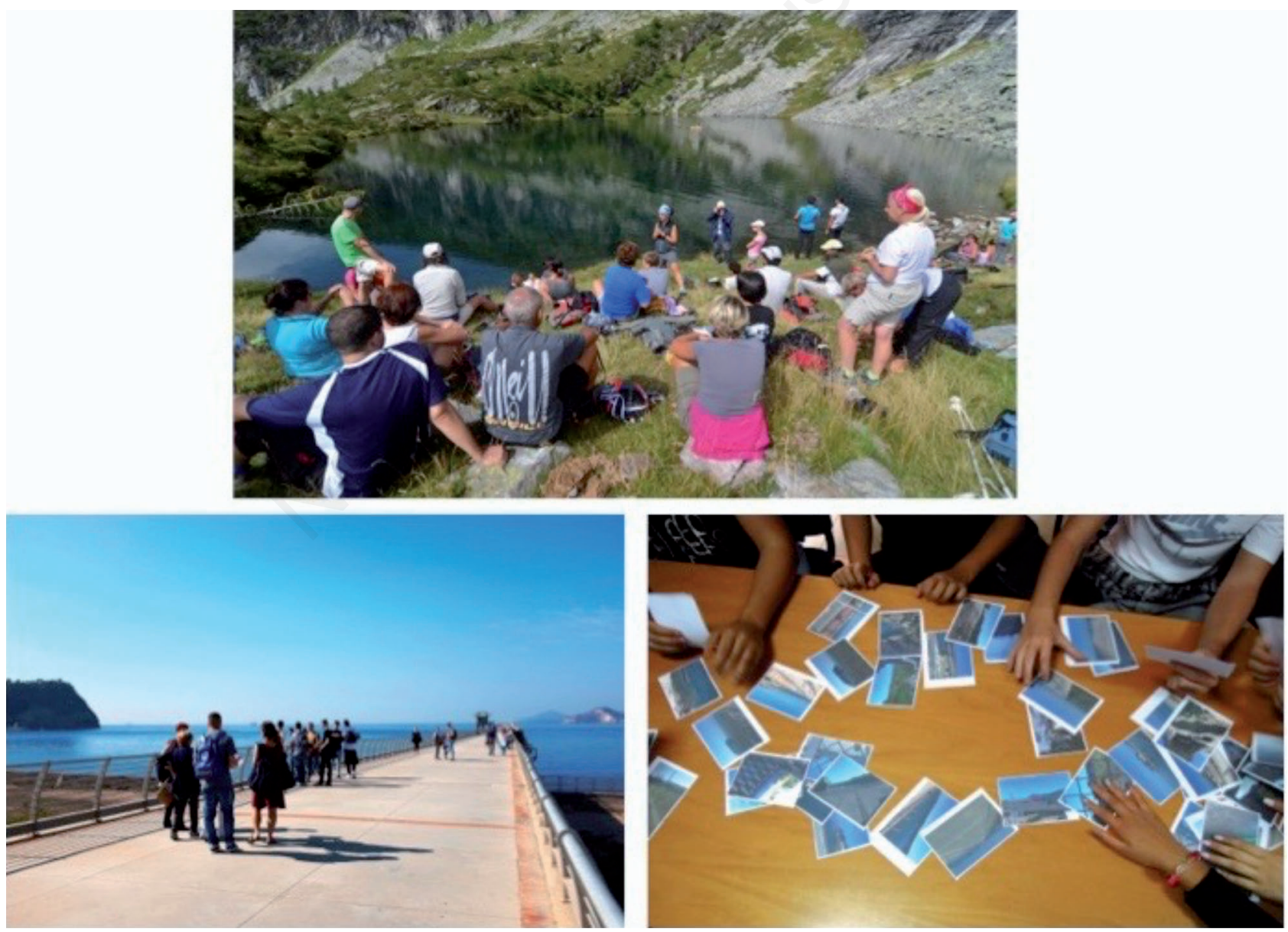

Fig. 3. Examples of activities carried out during Cammini LTER. Upper panel: scientist sharing with the public the sampling activities at the LTER mountain site Lake Paione Inferiore. Lower panel: secondary school students engaged in the Sea Futuring Tours at the LTER site Gulf of Naples, gathering and analysing materials to imagine possible futures for the sea. Pictures courtesy of Antonio Bergamino. 
eLTER-RI, at the European level: i) the relevance of wide scale comparative ecological analysis at different sites across ecological domains; ii) the possibility to develop specific research questions and complementary studies emerging from the long term observations at the LTER sites; iii) the necessity to deal with methods and data heterogeneity, by identifying harmonizing frameworks and fostering open science; and iv) the possibility to find and pursue a change in our vision of the relations between science and society, starting with different ways of communicating, in an open and empathic way. Most of these aspects are an expression of our scientific and cognitive approach to ecosystem study and they are all necessary to gaining knowledge and information on how ecosystems work and change through time.

In this conclusive musings I wish to make a step further, emphasizing some voices that are much overlooked, and which whisper that the LTER sites could be also the starting point where develop a deep connection with $\mathrm{Na}$ ture, entering in what is called the "soul of the place" (Harding, 2011): places in which one may spend time getting to know them intimately with intuition and feeling, whilst using the rational mind to find out about their ecology and about how humans have interacted with these places over the years. The age we live in is characterized by uncertainties, complexity and by crucial environmental and societal challenges (Millenium Ecosystem Assessment, 2005): according to many scholars, it is necessary, more than ever, to embrace a shift of perspectives for a transformative change (Leiserowitz et al., 2005; Ericson et al., 2014), which requires the elaboration of a deep and broadened form of subjectivity, in which humans identify also with non-humans, allowing to suspend the illusion of separateness (Naess, 1984; 1995; Carvalho, 2014; Geiger et al., 2018; Eisenstein, 2018).

Indeed, as evidenced by an increasing number of studies, scientific knowledge, new technology or governance alone cannot resolve the current ecological crisis and global sustainability challenges (Wamsler and Brink, 2018). They also require a broader cultural change and new approaches (Esbjörn-Hargens and Zimmermann, 2009; Dhiman and Marques, 2016; Wamsler and Brink 2018) that integrate in every ecological study and action an inner dimension, which include emotions, identities and values (Buchanan and Kern, 2017; Hedlund-de Witt, 2011; Ives et al., 2018, 2019). The inner world has been largely disregarded in scientific studies, but it is gaining increasing momentum in parallel scientific fields, such as neuroscience, ecopsychology and education. Within this context, some contemplative practices, such as meditation, have been proved to be crucial to open pathways (Mayer and Frantz, 2004; Panno, et al., 2017; Geiger et al., 2018; Wamsler, 2018), which could enable an expansion of empathy to include non-human subjects or, as in- spiringly David Abrams (1997) calls them, the "more than human world".

I decided not by chance to start this paper citing a famous sentence of the Buddhist monk Tich Nath Han, whose practices and insights aim at fostering the awareness of interconnectedness and "inter-being" (Carvalho, 2014), since he expresses in a poetical and vibrant way the deep interconnections that are at the foundation of any ecological and LTER study: interconnections among human beings, in a long chain that links the past to the present and to the future through LTER studies, and among us humans and non-human beings that surround us, in intertwined and mutually dependent functions and processes (Abrams, 1997).

\section{ACKNOWLEDGMENTS}

I think that every paper should start with a declaration of gratitude, deeply and openly appreciating the so many beings and events without those we simply could not be able to be here alive, willing to write and share our views and results. This is particularly true when speaking of LTER, a field of activity that intrinsically connect us with a vast community of non-human and human beings along the past and the future.

Keeping this in mind and with my gratitude extending all around, I will here acknowledge explicitly just a few persons, among the many I am indebted to: Caterina Bergami, Amelia De Lazzari, Alba L'Astorina, and Bruno Petriccione, who accompanied me in the years with emotions, thoughts, reflections, inspiration, and friendship. This work was presented as a plenary invited lecture at the XXIV Congress of the Italian Association of Oceanology and Limnology (Bologna, 5-7 June 2019). I am grateful to Domenico D'Alelio for his accurate revision of the paper and for the time of his life he dedicated to it.

Finally, I wish to dedicate the paper to four dearest colleagues who passed away recently: Lorenzo Busetto, Mario Contesini, Mario Giordano and Giuseppe Morabito.

Corresponding author: alessandra.pugnetti@ismar.cnr.it

Key words: plankton, LTER-Italy, aquatic ecosystems, affective ecology, meditation

Received: 16 November 2020.

Accepted: 7 December 2020.

This work is licensed under a Creative Commons Attribution NonCommercial 4.0 License (CC BY-NC 4.0).

${ }^{\circ}$ Copyright: the Author(s), 2020

Licensee PAGEPress, Italy

Advances in Oceanography and Limnology, 2020; 11:9508

DOI: 10.4081/aiol.2020.9508 


\section{REFERENCES}

Abrams D, 1997. The spell of the sensuous. Perception and language in a more-than-human world. Vintage Books. 352 pp.

Acri F, Bastianini M, Bernardi Aubry F, Boldrin A, Camatti E, et al., 2019. LTER Northern Adriatic Sea (Italy) marine data from 1965 to 2015 (Version 3) [Data set]. Zenodo. doi: 10.5281/zenodo. 3516717

Acri F, Bastianini M, Bernardi Aubry F, Camatti E, Boldrin A, et al., 2020. A long term (1965-2015) ecological marine database from the LTER-Italy site Northern Adriatic Sea: plankton and oceanographic observations. Earth Syst. Sci. Data 12:215-230.

Barbalet J, 2002. Science and Emotions. Sociol Rev 50:S132-150.

Barbiero G, 2011. Biophilia and Gaia: Two hypotheses for an affective ecology. J. Biourbanism 26:1-27.

Barbiero G, 2014. Affective Ecology for Sustainability. Visions for sustainability, 1: 20-30.

Barbiero G, 2017. [Ecologia affettiva].[Book in Italian]. Mondadori, $228 \mathrm{pp}$.

Bergami C, L'Astorina A, Pugnetti A, 2018. [I Cammini della rete LTER-Italia. Il racconto dell'ecologia in cammino].[Book in Italian]. CNR Edizioni. 180 pp.

Buchanan A, Kern ML, 2017. The benefit mindset: the psychology of contribution and everyday leadership. Int. J. Wellbeing 7:1-11.

Cappello P, 2013. [Questa libertà].[Book in Italian]. Rizzoli Editore. $180 \mathrm{pp}$.

Carvalho A, 2014. Subjectivity, ecology and meditation - Performing interconnectedness. Subjectivity 7:131-150.

Criscuolo L, Carrara P, Oggioni A, Pugnetti A, Antoninetti M, 2018a. Can VGI and mobile apps support Long Term Ecological Research? A test in remote areas of the Alps. In: G. Bordogna and P. Carrara P. (eds.), Mobile information systems leveraging volunteered geographic information for earth observation. Earth Systems Data and Models Vol 4. Springer, Cham.

Criscuolo A, Oggioni A, Campanaro A, 2018b. [La Citizen Science nei Cammini LTER]. In: C. Bergami, A. L'Astorina and A. Pugnetti A (eds.), [I Cammini della Rete LTER-Italia. Il racconto dell' ecologia in cammino].[Book in Italian]. CNR Edizioni.

D'Alelio D, 2016. The Mesothalassia Bike-Tour: (Re) discovering water by riding with scientists. Limnol. Oceanogr. Bull. 25: 1-7.

D'Alelio D, 2020. [La microgiungla del mare].[Book in Italian]. Hoepli Editore. 177 pp.

Davies SR, Horst M, 2016. Science communication: Culture, identity and citizenship. Palgrave Macmillan.

Dhiman S, Marques J, 2016. Spirituality and sustainability: New horizons and exemplary approaches. Springer, Cham.

Dick J, Orenstein DE, Holzer JM, Wohner C, Achard AL, Andrews C, et al., 2018. What is socio-ecological research delivering? A literature survey across 25 international LTSER platforms. Sci. Total Environ. 622-623: 225-1240.

Eisenstein C, 2018. Climate: a new story. North Atlantic Books. $306 \mathrm{pp}$.

Esbjörn-Hargens S, Zimmermann ME, 2009. Integral ecologyuniting multiple perspectives on the natural world. Integral Books, Boston.
Geiger SM, Otto S Schrader U, 2018. Mindfully green and healthy: An indirect path from mindfulness to ecological behavior. Front. Psychol. 8:2306.

Gardner H, 1983. Frames of mind: The theory of multiple intelligences. New York, Basic Books. 440 pp.

Gardner H, 1999. Intelligence Reframed. New York, Basic Books.

Gray DS, Colucci-Gray L, 2018. Laying down a path in walking: Student teachers' emerging ecological identities. Environ. Educ. Res. 25:341-364.

Haase P, Tonkin JD, Stoll S, Burkhard B, Frenzel M, Geijzendorffer IR, et al., 2018. The next generation of site-based long-term ecological monitoring: Linking essential biodiversity variables and ecosystem integrity. Sci. Total Environ. 613-614: 376-1384.

Haberl H, Winiwarter V, Andersson K, Ayres RU, Boone C, Castillo A, et al., 2006. From LTER to LTSER: conceptualizing the socioeconomic dimension of long-term socioecological research. Ecol. Soc. 11:13.

Harding S, 2011. Animate earth. Green Books: 258 pp.

Hedlund-de Witt A, 2011. The rising culture and worldview of contemporary spirituality: a sociological study of potentials and pitfalls for sustainable development. Ecol. Econ. 70:1057-1065.

Hensen V, 1887). [Ueber die Bestimmung des Plankton's oder des im Meere treibenden Materials an Pflanzen und Thieren].[Book in German]. Kiel: Schmidt \& Klaunig.

Ives CD, Abson DJ, von Wehrden H, Dorninger C, Klaniecki K, Fischer J, 2018. Reconnecting with nature for sustainability. Sustain. Sci.13:1389-1397.

Ives CD, Freeth R, Fischer J, 2019. Inside-out sustainability: The neglect of inner worlds. Ambio 49:208-217.

Koppman S, Cain CL, Leahey E, 2015. The joy of science: Disciplinary diversity in emotional accounts. Sci. Technol. Hum. Values 40:30-70

L'Astorina A, Bergami C, D'Alelio D, Dattolo E, Pugnetti A, 2018a. What is at stake for scientists when communicating ecology? Insight from the informal communication initiative "Cammini LTER". Visions for Sustainability 10:19-37.

L'Astorina A, Bergami C, Pugnetti A, 2018b. [Raccontare l'ecologia in cammino per aprirsi al mondo]. In: C. Bergami, A. L'Astorina and A. Pugnetti A (eds.), [I Cammini della Rete LTER-Italia. Il racconto dell'ecologia in cammino].[Book in Italian]. CNR Edizioni.

L'Astorina A, Pelusi A, Petrocelli A, Portacci G, Rubino F, 2018c. I Sea Futuring Tours nei Cammini LTER. In: C. Bergami, A. L'Astorina and A. Pugnetti A (eds.), [I Cammini della Rete LTER-Italia. Il racconto dell'ecologia in cammino].[Book in Italian]. CNR Edizioni.

Le Breton D, 2000. [Eloge de la marche].[Book in French]. Paris, Editions Métailé.

Magnuson JJ, 1990. Long-term ecological research and the invisible present. Bioscience 40:495-508.

Maturana H, Davila X, 2009. Preface to a beautiful book. In: J. Cull (ed.), The circularity of life - An essential shift for sustainability. J. Cull: 142 pp.

Maturana HR, Varela FJ, 1998. The tree of knowledge: The biological roots of human understanding. Revised edition. Boston: Shambhala Publications. 269 pp.

Mauz I, Peltola T, Granjou C, Van Bommel S, Buijs A, 2012. 
How scientific visions matter: insights from three long-term socio-ecological research (LTSER) platforms under construction in Europe. Environm. Sci. Policy 19:90-99.

Mayer FS, Frantz CM, 2004. The connectedness to nature scale: a measure of individuals' feeling in community with nature. J. Environ. Psychol. 24:503-515.

Michener WK, Brunt JW, Helly JJ, Kirchner TB, Stafford SG, 1997. Nongeospatial metadata for the ecological sciences. Ecol. Appl. 7:330-342.

Millennium Ecosystem Assessment, 2005. Ecosystems and human well-being, volume 1. Current state and trends. Washington: Island Press.

Minelli A, Bergami C, Oggioni A, Pugnetti A, 2018a. [Il mare, la ricerca ecologica a lungo termine e la scienza aperta: lavori in corso]. In: L'Astorina A, Di Fiore M, 2018. [Scienziati in affanno? Ricerca e Innovazione Responsabili (RRI) in teoria e nelle pratiche].[Book in Italian]. CNR Edizioni.

Minelli A, Oggioni A, Pugnetti A, Sarretta A, Bastianini M, Bergami C, et al., 2018b. The project EcoNAOS: vision and practice towards an open approach in the Northern Adriatic Sea ecological observatory. Res. Ideas Outcomes 4:e24224.

Mirtl M, Borer E, Djukic I, Forsius M, Haubold H, Hugo W, et al., 2018. Genesis, goals and achievements of Long-Term Ecological Research at the global scale: A critical review of ILTER and future directions. Sci. Total Environ. 626:14391469.

Moedas C, 2015. Freedom is absolutely necessary for scientific progress. Speech at European Commission. Brussels, 26 January 2015. Accessed: 24 August 2020. Retrieved from: https://ec.europa.eu/commission/commissioners/20142019/moedas/announcements/freedom absolutely-necessary-scientific-progress_en

Mollenhauer H, Kasner M, Haase P, Peterseil J, Wohner C, Frenzel M, et al., 2018. Long-term environmental monitoring infrastructures in Europe: observations, measurements, scales, and socio-ecological representativeness. Sci. Total Environ. 624:968-978.

Monbiot G, 2017. Forget 'the environment': We need new words to convey life's wonders. The Guardian, August 9. Accessed: 23 October 2020. Retrieved from: https://www.theguardian.com/commentisfree/2017/aug/09/forget-the-environment-new-words-lifes-wonders-language

Morabito G, Mazzocchi MG, Salmaso N, Zingone A, Bergami C, Flaim G, et al., 2018. Plankton dynamics across the freshwater, transitional and marine research sites of the LTERItaly Network. Patterns, fluctuations, drivers. Sci. Total Environ. 627:373-387.

Muller F, 2005. Indicating ecosystem and landscape organisation. Ecol. Indic. 5:280-294.

Naess A, 1984. Identification as a source of deep ecological attitudes, p. 256-270. In: M. Tobias (ed.), Deep Ecology. San Diego: Avant Books.

Naess A, 1995. Self-realization: An ecological approach to being in the world, p. 13-30. In: A. Drengon and Y. Inoue (eds.), The deep ecology movement. Berkeley, North Atlantic Books.

Panno A, Giacomantonio M, Carrus G, Maricchiolo F, Pirchio S, Mannetti L, 2017. Mindfulness, pro-environmental behavior, and belief in climate change: the mediating role of social dominance. Environ. Behav. 50:864-888.
Pereira HM, Ferrier S, Walters M, Geller GN, Jongman RHG, Scholes RJ, et al., 2013. Essential biodiversity variables. Science 339:277-278.

Peters DBC, 2010. Accessible ecology: synthesis of the long, deep, and broad. Trends Ecol. Evol. 25:592-601.

Petriccione B, 2018. I BioBlitz nei Cammini LTER. In: C. Bergami, A. L'Astorina and A. Pugnetti A (eds.), [I Cammini della Rete LTER-Italia. Il racconto dell'ecologia in cammino].[Book in Italian].

Pilotto F, Kühn I, Adrian R, Alber R, Alignier A, Andrews C, et al., 2020. Meta-analysis of multidecadal biodiversity trends in Europe. Nature Commun. 11:3486.

Pugnetti A, De lazzari A, Bergami C, L'Astorina, 2019. [Il dialogo dei ricercatori con la società civile. Esperienze e riflessioni dai cammini della Rete di Ricerca Ecologica a Lungo Termine LTER-Italia].[Article in Italian]. Museologia Scientifica Memorie 20:127-134.

Rogora M, Frate L, Carranza ML, Freppaz M, Stanisci A, Bertani I, et al., 2018. Assessment of climate change effects on mountain ecosystems through a cross-site analysis in the Alps and Apennines. Sci. Total Environ. 624:1429-1442.

Schentz H. Peterseil J, Bertrand N, 2013. EnvThes-interlinked thesaurus for Long Term Ecological Research, Monitoring, and Experiments, p. 824-832. Proceedings EnviroInfo 2013: Environmental Informatics and Renewable Energies. Aachen, Shaker Verlag.

Scovacricchi T, 2020. A glossary for open science, open geospatial and data curation. Zenodo. http://doi.org/10.5281/zenodo. 4302115

Shin N, Shibata H, Osawa T, Yamakita T, Nakamura M, Kenta $\mathrm{K}, 2019$. Toward more data publication of long-term ecological observations. Ecol. Res 35:700-707.

Singh SJ, Haberl H, Chertow MR, Mirtl M, Schmid M, 2013. Long term socio-ecological research: studies in society-nature interactions across spatial and temporal scales. Cham, Springer. pp. 588.

Solnit R, 2000. Wanderlust: A history of walking. New York, Penguin Books.

Tanentzap AJ, Morabito G, Volta P, Rogora M, Yan ND, Manca $\mathrm{M}, 2020$. Climate warming restructures an aquatic food web over 28 years. Global Change Biol. doi: 10.1111/gcb.15347

Vanderbilt K, Gaiser E, 2017. The International Long Term Ecological Research Network: a platform for collaboration. Ecosphere 8:e01697.

Vanderbilt KL, Blankman D, Guo X, He H, Lin C-C, Lu S-S, et al., 2010. A multilingual metadata catalog for the ILTER: issues and approaches. Ecol. Inform. 5:187-193.

Vanderbilt KL, Lin C-C, Lu S-S, Kassim AR, He H, Guo X, et al., 2015. Fostering ecological data sharing: collaborations in the International Long Term Ecological Research Network. Ecosphere 6:1-18.

Varela FJ, Thompson E, Rosch E, 1991. The embodied mind: Cognitive science and human experience. Cambridge, MIT Press.

Wamsler C, 2018. Mind the gap: The role of mindfulness in adapting to increasing risk and climate change. Sustain. Sci. 13:1121-1135.

Wamsler W, Brink E, 2018. Mindsets for sustainability: Exploring the link between mindfulness and sustainable climate adaptation. Ecol. Econom. 151:55-61. 
Wilson EO, 1984. Biophilia. Cambridge, Harvard University Press.

Wohner C, Peterseil J, Poursanidis D, Kliment T, Wilson M, Mirtl M, Chrysoulakis N, 2019. DEIMS-SDR - A web portal to document research sites and their associated data. Ecol. Inform. 51:15-24.

Zilioli M, Oggioni A, Tagliolato P, Pugnetti A, Carrara P, 2019.
Feeding Essential Biodiversity Variables (EBVs): actual and potential contributions from LTER-Italy. Nature Conservation 34:477-503.

Zingone A, D’Alelio D, Mazzocchi MG, Montresor M, Sarno D, LTER-MC team. 2019. Time series and beyond: multifaceted plankton research at a marine Mediterranean LTER site. Nature Conservation 34:273-310. 